Journal of Animal and Feed Sciences, 19, 2010, 379-397

\title{
The effect of intracerebroventricular infusion of leptin on the secretory activity of the somtotropic axis in fasted prepubertal lambs
}

\author{
A. Wójcik-Gladysz ${ }^{1,3}$, M. Wańkowska', T. Misztal', \\ D. Szczepankiewicz ${ }^{2}$, K. Romanowicz ${ }^{1}$ and J. Polkowska ${ }^{1}$
}

\author{
'The Kielanowski Institute of Animal Physiology and Nutrition, Polish Academy of Sciences \\ 05-110 Jabtonna, Poland \\ ${ }^{2}$ Poznan University of Life and Sciences, Department of Animal Physiology and Biochemistry \\ Wojska Polskiego 28, 60-637 Poznań, Poland
}

(Received 1 June 2010; revised version 15 July 2010; accepted 16 August 2010)

\begin{abstract}
The aim of the present study was to investigate the effect of exogenous leptin on somatotrophic axis regulation in prepubertal female lambs under conditions of acute undernutrition ( $72 \mathrm{~h}$ fasting). The analyses in fasted sheep revealed enhancement of immunoreactive (ir) somatostatin stores in perikarya of the periventricular (PEV) nucleus and in terminals of the median eminence (ME) $(\mathrm{P}<0.001)$, enhancement of growth hormone $(\mathrm{GH})$ mRNA expression in the adenohypophysis, diminishing of ir GH stores in somatotrophs in the adenohypophysis $(\mathrm{P}<0.001)$, and a rise in $\mathrm{GH}$ pulsatility $(\mathrm{P}<0.05)$ in the blood in comparison with standard-fed sheep. In fasted sheep infused with leptin, additional enhancement of ir somatostatin stores in the PEV nucleus and in the $\mathrm{ME}(\mathrm{P}<0.001)$, an increase in $\mathrm{GH}$ mRNA expression in the adenohypophysis $(\mathrm{P}<0.001)$, and augmentation of $\mathrm{GH}$ pulsatility $(\mathrm{P}<0.05)$ in the blood plasma were noted. In conclusion, acute undernutrition affects somatotrophic axis by enhancement of GII secretion via restraining of somatostatin output. Exogenous leptin additionally amplifies this effect by suppressing somatostatin release and increasing of $\mathrm{GH}$ secretion. The results provide evidence that leptin can regulate somatotrophic axis activity in prepubertal female lambs under conditions of acute fasting.
\end{abstract}

KEY WORDS: leptin, somatostatin, growth hormone, sheep

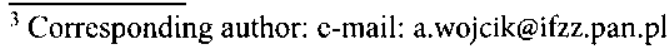




\section{INTRODUCTION}

Somatic growth processes in mammals are sensitive to the availability of energy from a feed. Acute modifications in the nutritional status of animal's organism affect hypothalamo-pituitary-somatotrophic (HPS) axis activity (Casanueva and Dieguez, 1999), and fasting or some food restriction resulted in variations of pulsatile growth hormone $(\mathrm{GH})$ secretion, the principal hormone of HPS axis coordinating postnatal growth in mammals (Polkowska et al., 1996). These modifications are due to secretion of growth hormone releasing hormone and somatostatin, the two main hypothalamic hormones involved in GH regulation (Brazeau et al., 1973, 1984).

In ruminants, chronic limitation of feed energy intake increases the synthesis and release of GH (Thomas et al., 1990). A long-term protein-restricted diet in growing female lambs augments mean plasma concentrations of $\mathrm{GH}$, which is associated with significant elevation of its pulse amplitude (Polkowska et al., 1996). These changes during restricted feeding appear to be mainly associated with the role of somatostatin (Gładysz et al., 2001). In growing female lambs, a stimulatory effect of restricted feeding on GH secretion also resulted from attenuation of somatostatin output (Gladysz et al., 2001).

The relationships between nutrition and growth processes have been extensively investigated, but knowledge about the exact mechanisms by which metabolic and nutritional factors contribute to the neuroendocrine regulation of $\mathrm{GH}$ secretion and integration of these processes at the central nervous system (CNS) level is insufficient. Recently, many efforts have been made to identify chemical factors, that can be considered links between the nutritional status of an organism and growth processes, and, leptin appears to be crucial in the network regulation of HPS axis secretory activity.

Leptin, discovered in 1994 (Zhang et al., 1994), is synthesized primarily by the adipose tissue and is a peptide able to pass the blood-brain barrier. The fact that leptin circulates in the blood in proportion to body adiposity and acts as a sensor of energy stores, underlines its important role as a peripheral hormonal signal carrying information about energy reserves of the organism to the hypothalamic centres involved in growth regulation (Casanueva and Dieguez, 1999; Baratta, 2002). The discovery of leptin receptor expression (Tartaglia et al., 1995) in the arcuate (ARC) and periventricular (PEV) nuclei of the hypothalamus, two centres involved simultaneously in the regulation of feeding behaviour and growth neuroendocrine system, confirms hypothesis (Baratta, 2002), that leptin could also exert its biological effects at the CNS level.

Some experiments in ruminants have shown that leptin affects $\mathrm{GH}$ secretion (Nagatani et al., 2000; Henry et al., 2001), but informations about its role in the 
regulation of HPS axis activity in these animals is still limited. The majority of them is based mainly on the effect of leptin on GH pulsatility in peripheral blood, moreover this effect has been observed primarily in animals subjected to a profound negative energy balance due to fasting (Henry et al., 1999, 2001; Nagatani et al., 2000; Morrison et al., 2001). In gonadectomized male sheep, the mean concentration of $\mathrm{GH}$ already augmented by fasting was additionally stimulated by administration of leptin (Nagatani et al., 2000). Intra-cerebroventricular infusion of leptin enhanced circulating $\mathrm{GH}$ in chronically undernourished sheep (Henry et al., 2001), but had no effect in ovariectomized, full-fed sheep (Henry et al., 1999). The above data indicate that in ruminants, contrary to rats, leptin affects GH secretion only under conditions of malnutrition.

Until now, there is no precise information about the mechanism underlying leptin's effect on HPS axis activity in ruminants. Due to the existence of important interspecies differences in the effects of fasting on GH secretion, transposing data on leptin mechanisms in rodents to ruminants is inappropriate and detailed investigations are needed.

In order to clarify our understanding of leptin's action on HPS axis in ruminants, a complex study was undertaken on the model of intact, prepubertal female sheep. The study encompassed three anatomical levels: the hypothalamus, the pituitary gland, and the peripheral circulation. The effects of exogenous leptin infused directly into the 3-rd ventricle of the brain were monitored in animals subjected to acute starvation. The examined endpoints included: a. the storage and release of immunoreactive (ir) somatostatin in the hypothalamus, b. expression of mRNA for $\mathrm{GH}$, storage and release of ir $\mathrm{GH}$ in the pituitary somatotrophs, and $\mathrm{c}$. $\mathrm{GH}$ profiles in the blood plasma, using immunohistochemistry, Real-Time PCR, and radioimmunological methods, respectively.

\section{MATERIAL AND METHODS}

\section{Animals and management}

The experiment was performed on immature female Polish Merino lambs. The animals were maintained indoor under natural lighting conditions $\left(52^{\circ} \mathrm{N}, 21^{\circ} \mathrm{E}\right)$ and fed a diet of commercial concentrates, with hay and water available ad libitum. Beginning at six months of age, plasma progesterone levels were monitored to determine the sexual maturity of animals. Additionally, ovaries were examined post-mortem. Implantation of a cannula into the third ventricle of the brain was performed one month prior to the first infusion, which took place in 7-monthold lambs. Specifically, animals were injected s.c. with $0.05 \mathrm{mg}$ atropine $/ \mathrm{kg}$ 
body weight (Polfa, Warsaw, Poland). Fifteen min later pentobarbital ("Vetbutal" Biowet, Pulawy, Poland) was administered i.v. at a dose of $10-20 \mathrm{mg} / \mathrm{kg}$ body weight until surgical levels of anaesthesia were reached. Anaesthetized animals were fixed in a stereotaxic apparatus using the procedure of Traczyk and Przekop (1963). Permanent stainless-steel guide cannulae $(0.6 \mathrm{~mm})$ were inserted into the third ventricle of the brain (position antero-posterior $31 \mathrm{~mm}$, lateral $0.5 \mathrm{~mm}$ along saggital plane 0.10 ) using the stereotaxic coordinate system of Welento et al. (1969) and secured to the scull with dental cement and screws. Each guide tube was fitted with an indwelling stilette to prevent a backflow of the cerebrospinal fluid. The correct placement of the guide cannula was established by the efflux of cerebral spinal fluid upon removal of the guide tube stilette after the surgery and before the infusion. Additionally, the placement of the guide cannulae was checked by inspections of the brain after decapitation. After the surgery, penicillinstreptomycin ("Scan-Vet", Poland) $0.04 \mathrm{ml} / \mathrm{kg}$ of body weight was given s.c. over four consecutive days. One day before the infusion a jugular venous catheter was inserted into each sheep and kept with heparinized saline (50 units heparin $/ \mathrm{ml}$ in $0.9 \% \mathrm{w} / \mathrm{v} \mathrm{NaCl}$ ).

\section{Experimental procedures}

Lambs were randomly divided into four groups: two standard-fed (fed a diet of commercial concentrates), and two fasted for $72 \mathrm{~h}$. All groups had free access to water during the all experiment. One standard and one fasted group were infused intracerebroventricularly (icv) with leptin: standard $+L, n=6$; fasted $+L, n=9$ $(25 \mu \mathrm{g} / 120 \mu \mathrm{l} / \mathrm{h}$, total dose $100 \mu \mathrm{g}$ per sheep) and the remaining standard and fasted groups were infused with the vehicle (Ringer - Locke solution; $120 \mu \mathrm{l} / \mathrm{h}$ - control groups: standard $+V, n=9$; fasted $+V, n=9$ ). The icv infusions were performed in a series of four 1-h infusions from 8.30 to 14.00 at $30 \mathrm{~min}$ intervals for three consecutive days, using a CMA 100-microinjection pump (CMA/Microdialysis $\mathrm{AB}$, Stokholm, Sweden). On the day before the infusions (day 0 ) and on the day of the third infusion (day 3), blood samples were collected from 8.00 to 14.00 every ten min. Samples were centrifuged and plasma was stored at $-20^{\circ} \mathrm{C}$ until analysis. Immediately after the experiment the sheep were slaughtered by decapitation in the licensed slaughterhouse after anaesthesia with an i.v. injection of sodium pentobarbitone ( $20 \mathrm{mg} / \mathrm{kg}$; Biochemie $\mathrm{GmbH}$, Kundl, Austria) and brains were fixed in situ in order to obtain the hypothalamic and pituitary tissues for further immunohistochemical analysis.

Highly purified recombinant ovine leptin was kindly donated by Prof. Arieh Gertler (the Hebrew University of Jerusalem, Rehovot, Israel). During the experiment the animals were kept in comfortable cages where they could lie 
down. All described procedures were approved by the III Local Ethic Committee affiliated with the Warsaw Agriculture University (Opinion Number 69/2001).

\section{Immunohistochemical procedure}

Immunohistochemical procedures were performed on the following groups of sheep ( $\operatorname{standard}+V, n=6$; fasted $+V, n=6$; standard $+L, n=6$; fasted $+L, n=6$ ).

Immediately after decapitation, each brain was perfused via both carotid arteries with $1500 \mathrm{ml} 0.1 \mathrm{M}$ phosphate buffered saline (PBS, Sigma, St. Louis, USA) and subsequently with $2000 \mathrm{ml} 0.1 \mathrm{M}$ PBS containing $4 \%(\mathrm{w} / \mathrm{v})$ formaldehyde (SigmaAldrich, Seelze, Germany), pH 7.4. The hypothalami and pituitaries were dissected $20 \mathrm{~min}$ after the beginning of perfusion and postfixed for $72 \mathrm{~h}$ (hypothalami) or $48 \mathrm{~h}$ (pituitaries) by immersion in the same fixative and then washed with 0.01 M PBS. Hypothalami jointly with the median eminence (ME) and pituitary stalk were cryoprotected in a $20 \%$ sucrose solution in $0.1 \mathrm{M}$ PBS at $4^{\circ} \mathrm{C}$ for at least two days. The hypothalamic blocks were cut on a cryostat (Jung CM 1500, Leica Instruments $\mathrm{GmbH}$, Nussloch, Germany) into $30-\mu \mathrm{m}$-thick sections along the coronal plane between the optic chiasma and the mamillary body, through the anterior hypothalamic area, the medial basal hypothalamus $(\mathrm{MBH})$ including the $\mathrm{ME}$, and the pituitary stalk. Hypothalamic nuclei were identified using the atlas of the sheep brain developed by Welento et al. (1969). Then sections were processed for immunohistochemistry. Pituitaries were dehydrated in graded series of ethanol, embedded in paraplast (Sigma, St. Louis, USA) and then cut through the entire gland at $4 \mu \mathrm{m}$ thickness in the sagital plane. Brain sections were washed in $0.1 \mathrm{M}$ PBS and then incubated for $4 \mathrm{~h}$ in $1 \%$ hydrogen peroxide (Chempur, Piekary Śląskic, Poland) in $0.1 \mathrm{M}$ PBS, $24 \mathrm{~h}$ in $3 \%$ preimmune lamb serum in $0.1 \mathrm{M}$ PBS and in $0.5 \%$ Triton X-100 in $0.01 \mathrm{M}$ PBS for $30 \mathrm{~min}$. Pituitary sections were deparafined, rehydrated, washed in $0.01 \mathrm{M}$ PBS, incubated for $30 \mathrm{~min}$ in $2 \%$ preimmune lamb serum in $0.01 \mathrm{M}$ PBS and $30 \mathrm{~min}$ in $0.1 \%$ hydrogen peroxide in $0.01 \mathrm{M}$ PBS. The hypothalamic sections were incubated with primary antiserum, rabbit anti-somatostatin ref. 64714 (ICN Biomedicals Inc. Aurora, Ohio, USA) diluted $1: 1000$, for 14 days at $4^{\circ} \mathrm{C}$, and the pituitary sections were incubated with primary antiserum anti-hGH ref. 19538 (the methodological details and the specificity of these antibodies were described by Dubois, 1971) diluted 1:400 for $48 \mathrm{~h}$ at $4^{\circ} \mathrm{C}$. After incubation with primary antibodies, hypothalamic and pituitary sections were rinsed in $0.01 \mathrm{MPBS}$, incubated for $2 \mathrm{~h}$ at room temperature $\left(\sim 20^{\circ} \mathrm{C}\right)$ with secondary antibody (sheep anti-rabbit $\mathrm{Ig}[\mathrm{H}+\mathrm{L}]$ labelled with peroxidase; Biorad, Steenvoorde, France), at a dilution of 1: 40 in 0.1\% normal lamb serum in $0.01 \mathrm{M}$ PBS. The colour reaction was developed by incubating sections with $0.05 \%$ 3'3-diaminobenzidine tetrahydrochloride chromogen (Sigma, St. Louis, 
USA) and $0.001 \%$ hydrogen peroxide in $0.05 \mathrm{M}$ Tris buffer (ICN, Aurora, $\mathrm{OH}$, USA).

In the control staining, primary antiserum was replaced with the same dilution of rabbit serum. To evaluate the specificity of staining, somatostatin antiserum was pre-adsorbed using synthetic somatostatin (cyclic Clin-Midy, France). Somatostatin antiserum was mixed with $10 \mu \mathrm{g} / \mathrm{ml}$ of synthetic antigen, preincubated for $24 \mathrm{~h}$ at $4^{\circ} \mathrm{C}$ and then used for immunohistochemical staining instead of the primary antibody. To evaluate the specificity of staining for $\mathrm{GH}$, antiserum was preadsorbed by using synthetic hGH (Sigma, St Louis USA). Ovine GH antiserum was mixed with $4 \mu \mathrm{g} / \mathrm{ml}$ of synthetic antigen, preincubated for $24 \mathrm{~h}$ at $4^{\circ} \mathrm{C}$ and then used for immunohistochemical staining instead of the primary antibody. Neither control exhibited any specific staining (data not shown).

\section{Real-Time PCR}

Pituitaries from standard $+V(n=3)$, fasted $+V(n=3)$, fasted $+L(n=3)$ groups of lambs, were isolated and frozen at $-80^{\circ} \mathrm{C}$ for further GH RNA isolation. Total RNA from each pituitary was isolated using NucleoSpin ${ }^{\circledR}$ RNA II kits (MachereyNagel, Duren, Germany) according to the manufacturer's protocol. Isolated RNA was subjected to rDNAse digestion in order to remove contaminating DNA (NucleoSpin ${ }^{\circledR}$ RNA II kit Macherey-Nagel, Duren, Germany). RNA amount and quality were analysed spectrophotometrically (Gene Quant pro, Biochrom Ldt., Cambridge, England). Reverse transcription of $1.5 \mu \mathrm{g}$ of isolated RNA was performed using DyNAmo ${ }^{\text {TM }}$ SYBR ${ }^{\circledR}$ Green 2-Step qRT-PCR kits (Finnzymes, Espoo, Finland) according to the manufacturer's instructions. A negative control without reverse transcriptase that was used in further analyses was also prepared. Primers for GH and internal standard GADPH were designed using Primer 3 software (http://frodo.wi.mit.edu/primer3/input.htm). The following primer pairs were used: GH (F) primer: 5' CAGGTTGCCTTCTGCTTCTC 3' and (R) primer: 5' ACCAGGCTGTTGGTGAAGAC 3' (product size $161 \mathrm{bp}$ ). A housekeeping gene (internal standard) GAPDH (glyceraldehydes-phosphodehydrogenase) was amplified using primers (F): 5' TGACCCCTTCATTGACCTTC 3' and (R): 5'GATCTCGCTCCTGGAAGATG 3' (product size 143 bp). DyNAmo ${ }^{\text {TM }}$ SYBR® Green 2-Step qRT-PCR kit (Finnzymes, Espoo, Finland) was used to perform RTPCR amplification in a total volume of $25 \mu l$ under the following conditions: initial denaturation at $95^{\circ} \mathrm{C}$ for $15 \mathrm{~min}$, followed by 35 cycles with a temperature profile of $94^{\circ} \mathrm{C}$ for $10 \mathrm{~s}, 56^{\circ} \mathrm{C}$ for $30 \mathrm{~s}$ for GH and GAPDH, respectively, and $72^{\circ} \mathrm{C}$ for $30 \mathrm{~s}$. Real-time PCR reactions were performed using a Corbet Rotor Gene Instrument 3000 (Australia). Melting curves were also determined (not shown). Analyses prepared for GH and GAPDH genes were analysed in the same sample. 
Data were analysed using Rotor Gene Software Version 6.0 and were shown as the ratio of analysed gene expression to GADPH.

\section{Morphometric analyses}

A projection microscope Nikon type 104 (Nikon Corporation, Yokohama, Japan) was used for histological analyses of hypothalamic and pituitary sections. Staining was analysed using a Lucia image analysis computer system version 3.51 ab (Laboratory Imaging Ltd., Prague, Czech Republic). Images of stained sections were projected by camera (Panasonic KR222, Matsushita Electric Industrial Co, Osaka, Japan) to a colour monitor. Pictures were adjusted for optimal contrast, fixed at the same brightness levels, converted to grey and saved in the buffering system. The analyses for statistical purposes were performed with a $20 \mathrm{x}$ objective lens for somatostatin perikarya and $4 \mathrm{x}$ for the nerve terminals in the ME and $x 40$ objective for the pituitary GH cells. Two parameters, 1. percent area - percentage of total area that exhibited positive staining (in the pituitary gland indicates percent of stained cells), and 2. integral density - the sum of individual optical densities of each pixel in the area being measured, describe the amount of substance in histological sections, expressed in relative units. Quantitative analysis was performed for each hypothalamus and each anterior pituitary gland in the subareas of sections of the PEV nucleus, the ME and the adenohypophysis using threshold function to select a range of grey values that were optically identified as positive staining. All other values were referred to as nonstaining. Before measurements, the images were processed by substraction of background and removal of artifacts. Frame size was kept constant for the duration of the image analysis. The analyses of percentage area and integral densities for the immunoproduct of the ir somatostatin nerve terminals were estimated in the delineated area containing the middle part of the ME. Measurements were performed on every fourth section ( 24 sections per animal) for a total area of $100 \mathrm{~mm}^{2}$ for each hypothalamus. The immunoproduct of the ir somatostatin perikarya was analysed on both sides of the third ventricle in the PEV nucleus. The quantification of data was based on 24 measurements in 12 sections for PEV nucleus in the subarea of interest $\left(0.2293 \mathrm{~mm}^{2} /\right.$ field $)$. The analyses for pituitary GH cells were made in the 4 sections of each adenohypophysis, using every $40^{\text {th }}$ mounted and stained section ( 16 fields of $0.0837 \mathrm{~mm}^{2}$ measured in each section).

\section{Radioimmunology analyses}

Analyses were performed in the standard $+V$ group, $n=9$; fasted $+V$ group, 
$\mathrm{n}=9 ;$ standard $+\mathrm{L}$ group, $\mathrm{n}=6$; fasted $+\mathrm{L}$ group, $\mathrm{n}=9$.

Plasma progesterone was assayed in duplicates of $100 \mu \mathrm{l}$ aliquots by a direct RIA method routinely used in our laboratory in accordance with the procedure described by Stupnicki and Kula (1982) with a sensitivity of $6.2 \mathrm{pg} / \mathrm{ml}$. The intraassay coefficient of variation was $<10 \%$.

Plasma GH was estimated in duplicate by double-antibody RIA in accordance with Slaba et al. (1994) using pituitary derived bGH, purified by chromatography on SE-Sephadex C-50 in sodium acetate buffer for iodination and reference standards. The first antibody was produced in rabbits against pituitary-derived bGH NIDDK-GH-B-1003A. The assay detection limit was $0.034 \mathrm{ng}$ corresponding to $0.68 \mathrm{ng} / \mathrm{ml}$ plasma per sample. The intra-assay and inter-assay $\mathrm{CV}$ averaged 5.9 and $10.2 \%$, respectively.

\section{Statistical analyses}

The quantitative measurements taken from each section for each ME, PEV nucleus or adenohypophysis were averaged to obtain a mean estimate for each $\mathrm{ME}$, each nucleus and each adenohypophysis within each animal. Then, the mean data were pooled to represent: standard $+\mathrm{V}$, fasted $+\mathrm{V}$, standard $+\mathrm{L}$, fasted $+\mathrm{L}$ groups. The data were analysed by the non-parametric Walda-Wolfowitz test using Statistica 6.0 PL software (StatSoft Inc., Tulsa, OK, USA). The data are reported as the mean percentage (for all groups $n=6$ ) \pm SEM of the total area that exhibited positive staining and mean relative units \pm SEM of integral density. Significance was defined at the $\mathrm{P}<0.001$ level.

Data of RIA are presented as mean ( $n=9$ or $n=6$ per group, respectively) \pm SEM. The mean concentration of $\mathrm{GH}$ for individual animals was calculated from the area under the curve (the sum of trapezoid areas between the curve and the abscissa). Pulse characteristics of GH were calculated using the Pulsar Computer Program Version 3.01 developed by Merriam and Watcher (1982) and adapted to operate on an IBM-PC. The cut-off parameters $G_{(n)}$ were set at a $5 \%$ error rate assuming a normal distribution of data. Analyses were performed individually for every lamb and included the entire sampling period. The level of significance for differences between groups for data obtained from plasma GH analysis was calculated using a one-way analysis of variance, followed by a post hoc NewmanKeuls test (for mean concentration and amplitude of pulse) or the Kruskal-Wallis test, the nonparametric equivalent of ANOVA for number of pulses (Statistica 6.0 PL software; StatSoft Inc., Tulsa, OK, USA). Significance was defined at the $\mathrm{P}<0.05$ level. 


\section{RESULTS}

Animals. The progesterone concentrations in the blood plasma of all animals did not exceed $0.5 \mathrm{ng} / \mathrm{ml}$ in each sheep. Inspection of their ovaries revealed no corpora lutea and at least one dominant ovarian follicle of about 6-7 $\mathrm{mm}$ in diameter.

Immunoreactivity of somatostatin in the hypothalamus. Microscopic observation revealed that in the sheep from all investigated groups the localization of ir somatostatin in hypothalamic neurons was similar. Immunoreactive somatostatin perikarya created a distinct centre located in the PEV nucleus extending from the suprachiasmatic area in the anterior hypothalamus up to the paraventricular zone in the medial basal hypothalamus. Immunoreactive somatostatin nerve terminals in the ME were arranged in its external zone across the entire width of this organ from its postero-anterior part to the pituitary stalk, showing the greatest accumulation in the medial part.

In the hypothalamus of standard-fed sheep the number of visible somatostatin ir cells and their intensity of staining were very weak (Figure la). In the ME, the amount of ir somatostatin matcrial was scarce throughout all cross-sections from the anterior part of the ME to the pituitary stalk (Figure 2a). In the standard-fed sheep infused with leptin, no morphological changes in the somatostatin perikarya or nerve terminals were noticed compared with standard-fed sheep (Figures $1 \mathrm{~b}$ and $2 b$ ).

In contrast to standard-fed sheep, in fasted animals, clear-cut differences in the number of ir somatostatin perikarya, density of ir somatostatin fibres and ir somatostatin nerve terminals were seen: the somatostatin periventricular centre displayed numerous cells strongly filled with immunoproduct (Figure 1c). Microscopic observations of somatostatin located in the terminals of the ME revealed that ir material was abundant in the fasted group of sheep throughout all cross-sections from the anterior part to the caudal part of the ME (Figure 2c).

In fasted sheep infused with leptin, an additional, marked increase in immunostaining and visible number of somatostatin perikarya in the PEV nucleus and ir material in the nerve terminals of the ME, with a striking amount of ir somatostatin in the terminals surrounding capillaries was found (Figures $1 \mathrm{~d}$ and 2d).

Image analysis demonstrated that the percentage of areas exhibiting positive staining and integral density for ir somatostatin perikarya in the PEV nucleus and ir somatostatin in nerve terminals in the $\mathrm{ME}$ were significantly higher $(\mathrm{P}<0.001)$ in fasted $+\mathrm{V}$ than in standard $+\mathrm{V}$ and standard $+\mathrm{L}$ groups of sheep. Both parameters were also significantly higher $(\mathrm{P}<0.001)$ in the fasted $+\mathrm{L}$ compared to the fasted $+\mathrm{V}$ groups of sheep (Figures le and 2e). 

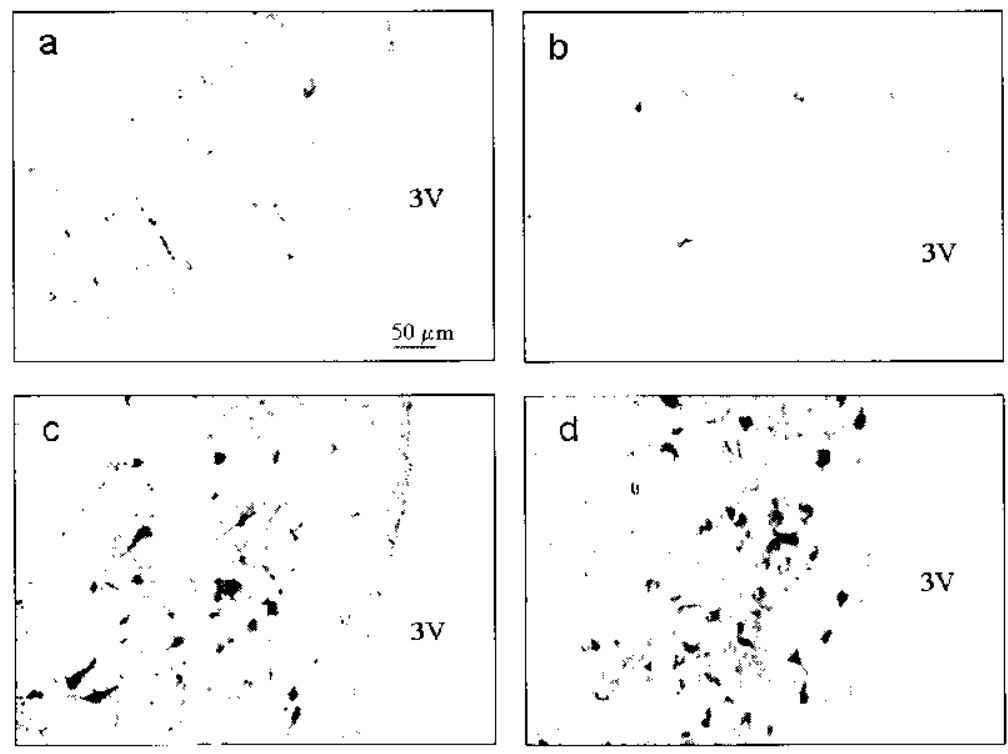

e

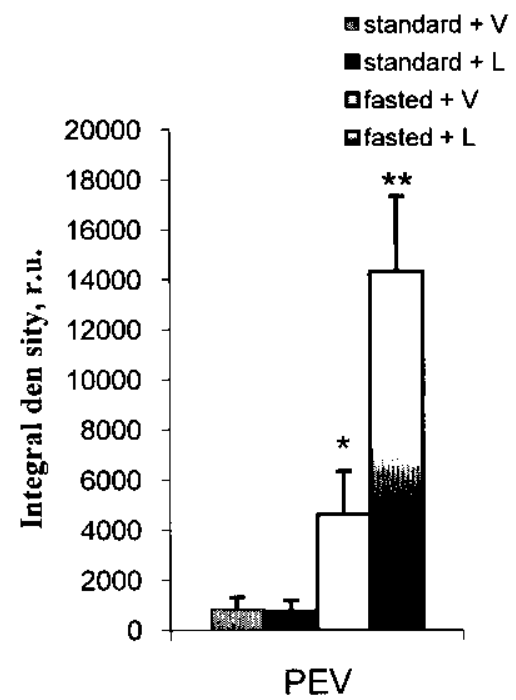

Figures l a-d. Population of immunoreactive somatostatin perikarya and fibres in the periventricular nucleus of two representative pairs of lambs from groups fed a standard diet (a-b) and fasted $72 \mathrm{~h}$ (c-d), after vehicle (a-c) or leptin (b-d) infusions. 3-third ventricle of the brain, scale bars: $50 \mu \mathrm{m}$. e. The percentage (left panel) and integral density (right panel) for the nerve elements expressing immunoreactivity for somatostatin in the periventricular nucleus of lambs from groups fed the standard dict and fasted $72 \mathrm{~h}$ after vehicle and leptin infusions to the $3^{\text {rd }}$ ventricle. Mcans $\pm S E M$; $\because$ differ at $\mathrm{P}<0.001$ 

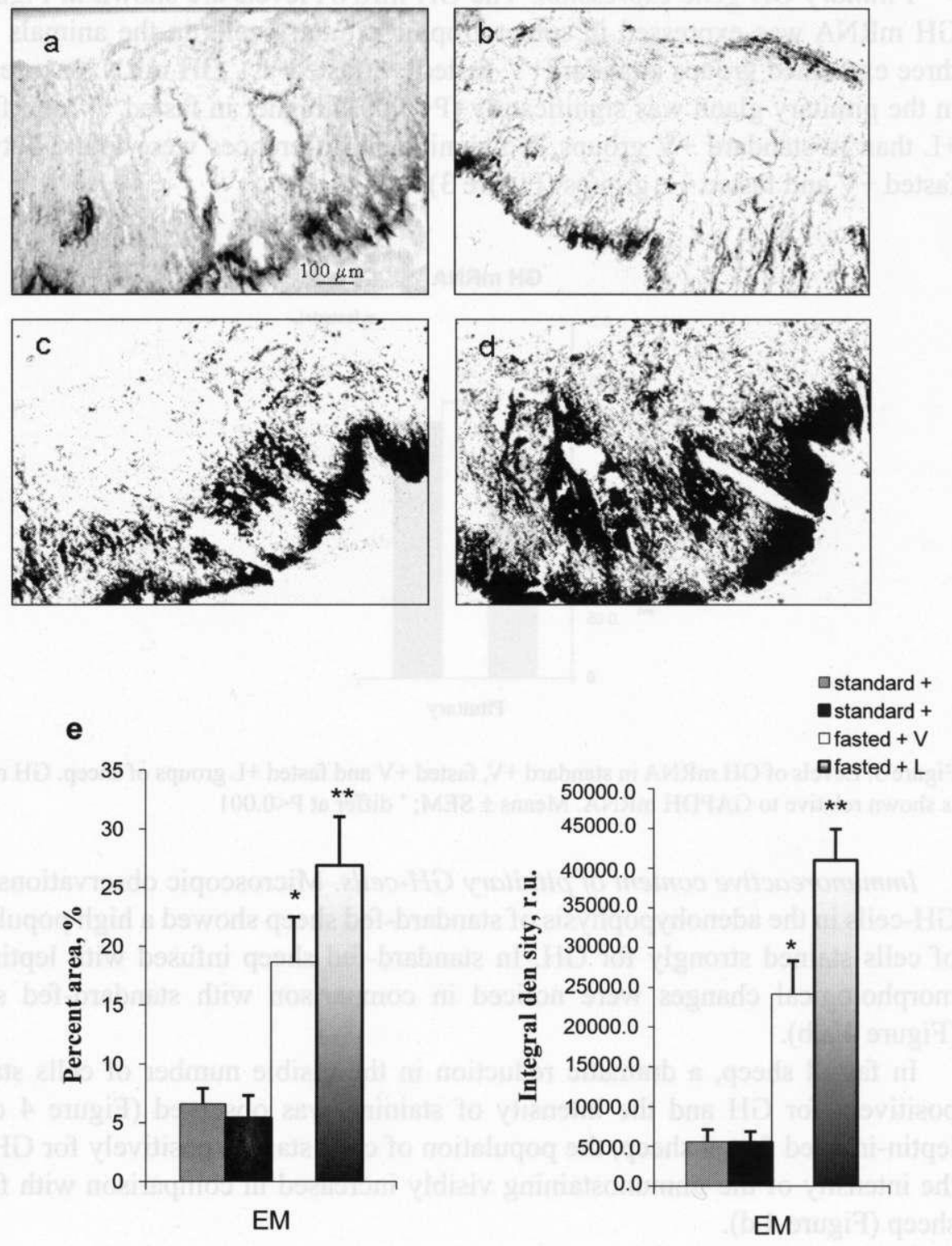

Figure 2 a-d. Immunoreactive somatostatin terminals in the medial part of the median eminence of two representative pairs of lambs from groups fed a standard diet (a-b) and fasted $72 \mathrm{~h}$ (c-d), after vehicle (a-c) or leptin (b-d) infusions; scale bars: $100 \mu \mathrm{m} .2 \mathrm{e}$. The percentage (left panel) and integral density (right panel) for the nerve terminals expressing immunoreactivity for somatostatin in the periventricular nucleus of lambs from groups fed standard diet and fasted $72 \mathrm{~h}$ after vehicle and leptin infusions to the $3^{\text {rd }}$ ventricle. Means \pm SEM; $" *$ differ at $\mathrm{P}<0.001$ 
Pituitary GH gene expression. The GH mRNA levels are shown in Figure 3. $\mathrm{GH}$ mRNA was expressed in somatotrophic pituitary cells in the animals from three examined groups (standard $+\mathrm{V}$, fasted $+\mathrm{V}$, fasted $+\mathrm{L}$ ). $\mathrm{GH}$ mRNA expression in the pituitary gland was significantly $(\mathrm{P}<0.001)$ higher in fasted $+\mathrm{V}$ and fasted $+\mathrm{L}$ than in standard $+\mathrm{V}$ groups. No significant differences were found between fasted $+\mathrm{V}$ and fasted $+\mathrm{L}$ groups (Figure 3 ).

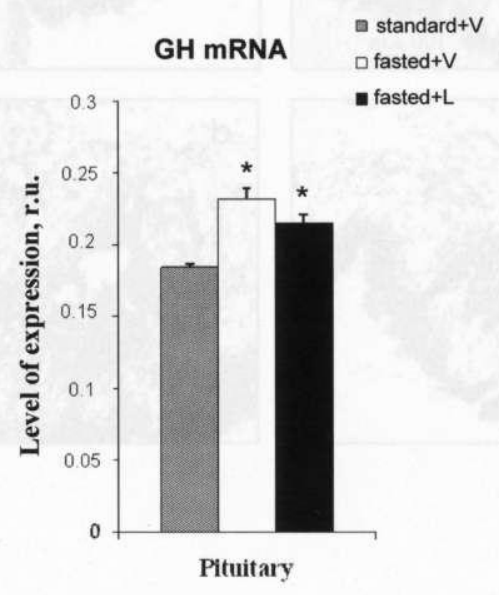

Figure 3. Levels of $\mathrm{GH}$ mRNA in standard $+\mathrm{V}$, fasted $+\mathrm{V}$ and fasted $+\mathrm{L}$ groups of sheep. GH mRNA is shown relative to GAPDH mRNA. Means $\pm \mathrm{SEM}$; ${ }^{*}$ differ at $\mathrm{P}<0.001$

Immunoreactive content of pituitary GH-cells. Microscopic observations of ir GH-cells in the adenohypophysis of standard-fed sheep showed a high population of cells stained strongly for GH. In standard-fed sheep infused with leptin, no morphological changes were noticed in comparison with standard-fed sheep (Figure $4 \mathrm{a}, \mathrm{b}$ ).

In fasted sheep, a dramatic reduction in the visible number of cells stained positively for $\mathrm{GH}$ and the intensity of staining was observed (Figure $4 \mathrm{c}$ ). In leptin-infused fasted sheep, the population of cells stained positively for $\mathrm{GH}$ and the intensity of the immunostaining visibly increased in comparison with fasted sheep (Figure $4 \mathrm{~d}$ ).

The microscopic observations were supported by quantitative computer estimation. The percentage of ir GH-positive cells and the density of ir GH material were significantly lower $(\mathrm{P}<0.001)$ in adenohypophyses of the fasted $+\mathrm{V}$ compared with the standard $+\mathrm{V}$ groups of sheep. Both parameters were significantly higher $(\mathrm{P}<0.001)$ within the fasted $+\mathrm{L}$ compared with the fasted $+\mathrm{V}$ groups of sheep (Figure 4 e). No differences were found between the standard $+\mathrm{V}$ and standard $+\mathrm{L}$ groups. 

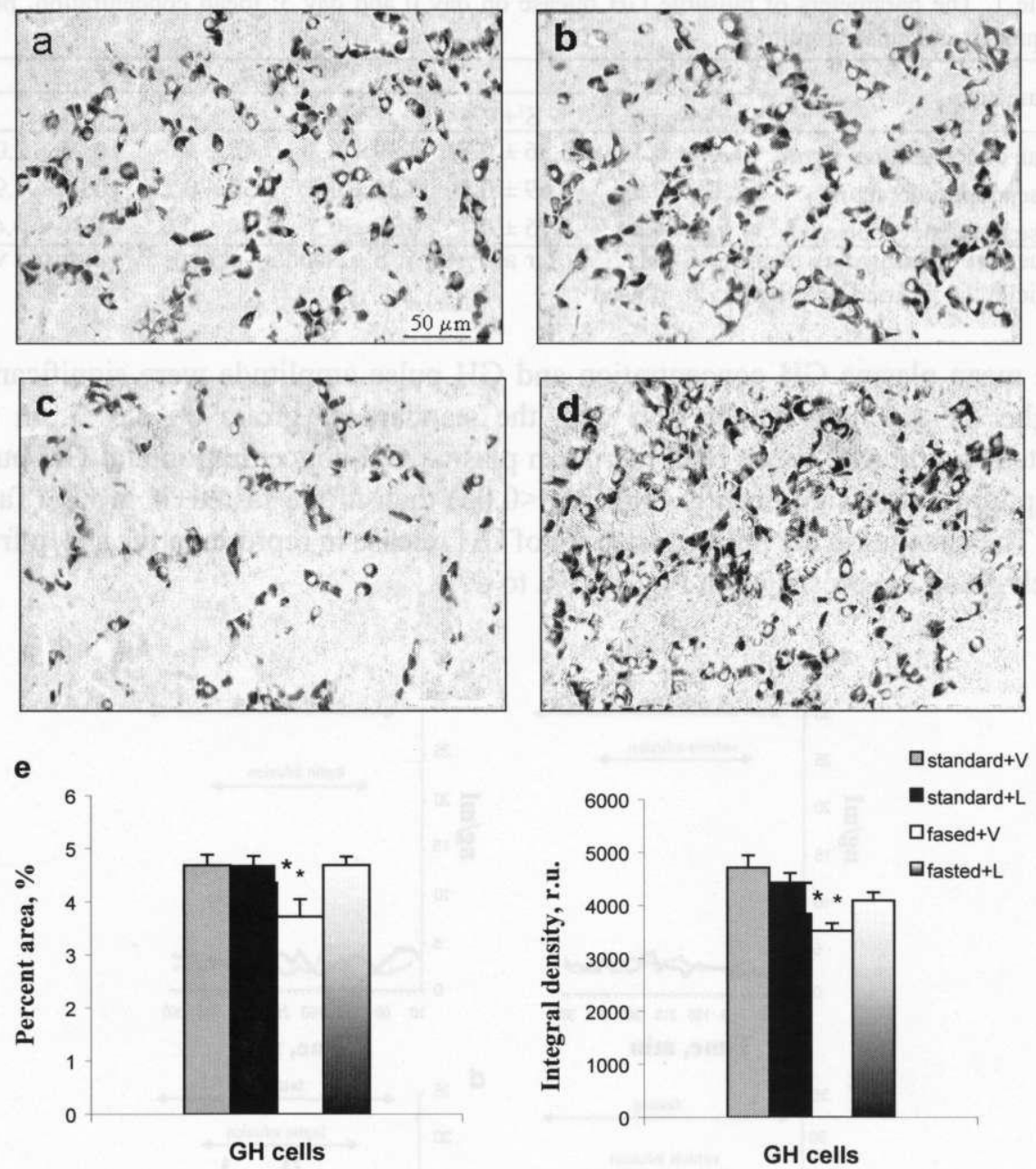

Figures 4 a-d. Population of immunoreactive somatotrophs in the adenohypophyses of two representative pairs of lambs from groups: fed a standard diet (a-b) and fasted $72 \mathrm{~h}(\mathrm{c}-\mathrm{d})$, after vehicle (a-c) or leptin (b-d) infusions; scale bars: $50 \mu \mathrm{m}$. e. The percentage (left panel) and integral density (right panel) for the cells expressing immunoreactivity for growth hormone in the adenohypophysis of lambs from groups fed standard diet and fasted $72 \mathrm{~h}$, after vehicle and leptin $(25 \mu \mathrm{g})$ infusions to the $3^{\text {rd }}$ ventricle. Means \pm SEM; ${ }^{*}$ differ at $\mathrm{P}<0.001$

GH pulsatility. On day 0 in the animals from four examined groups (before infusion) the mean $\mathrm{GH}$ plasma concentration and the $\mathrm{GH}$ pulsatily parameters (pulse amplitude and GH pulse frequency) were similar (Table 1). On day 3 no changes in the above $\mathrm{GH}$ pulsatily parameters were noticed in either standard $+\mathrm{V}$ or standard $+\mathrm{L}$ group in comparison with day 0 . In the fasted $+\mathrm{V}$ group of sheep, 
Table 1. The parameters of pulsatile GH release on day 0 and day 3: mean concentration, pulse frequency and pulse amplitude

\begin{tabular}{|c|c|c|c|c|c|}
\hline \multirow{2}{*}{ Parameters } & \multirow{2}{*}{$\begin{array}{c}\text { Day } 0 \\
\text { all groups }\end{array}$} & \multicolumn{4}{|c|}{ Day 3} \\
\hline & & $\mathrm{S}^{1}+\mathrm{V}^{2}$ & $\mathrm{~S}+\mathrm{L}^{3}$ & $\mathrm{~F}^{4}+\mathrm{V}$ & $\mathrm{F}+\mathrm{L}$ \\
\hline D nol & $3.45 \pm 0.5$ & $3.36 \pm 0.71$ & $3.39 \pm 0.3$ & $7.48 \pm 1.0^{*}$ & $10.01 \pm 2.0^{* *}$ \\
\hline Pulse amplitude, $\mathrm{ng} / \mathrm{ml}$ & $2.18 \pm 0.5$ & $2.69 \pm 0.5$ & $3.20 \pm 0.6$ & $5.50 \pm 0.2^{*}$ & $10.09 \pm 1.9^{* *}$ \\
\hline Pulse frequency, pulse $/ 6 \mathrm{~h}$ & $6.6 \pm 0.34$ & $5.75 \pm 0.4$ & $6.20 \pm 0.3$ & $5.60 \pm 0.5$ & $5.40 \pm 0.4$ \\
\hline
\end{tabular}
values are presented as means \pm SEM; $; "$ "** differ at $\mathrm{P}<0.05 ; \mathrm{S}$ - standard group; ${ }^{2} \mathrm{~V}$ - infused with vehicle; ${ }^{3} \mathrm{~L}$ - infused with leptin; ${ }^{4} \mathrm{~F}$ - fatsed

the mean plasma GH concentration and GH pulse amplitude were significantly higher $(\mathrm{P}<0.05)$ in comparison with the standard $+\mathrm{V}$ group on day 3 . In the fasted $+\mathrm{L}$ group of sheep both the mean plasma $\mathrm{GH}$ concentration and $\mathrm{GH}$ pulse amplitude were significantly higher $(\mathrm{P}<0.05)$ than in the fasted $+\mathrm{V}$ group (Table 1). The changes in the pulsatile pattern of $\mathrm{GH}$ release in representative sheep from each group are presented in Figures 5 a to $d$.

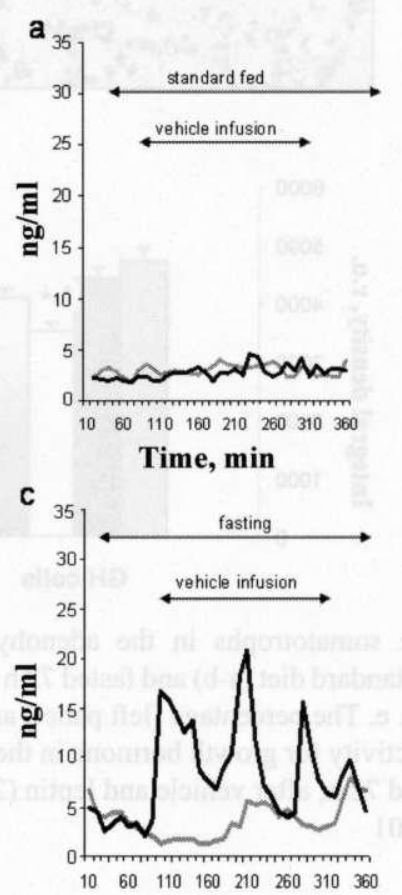

Time, $\min$

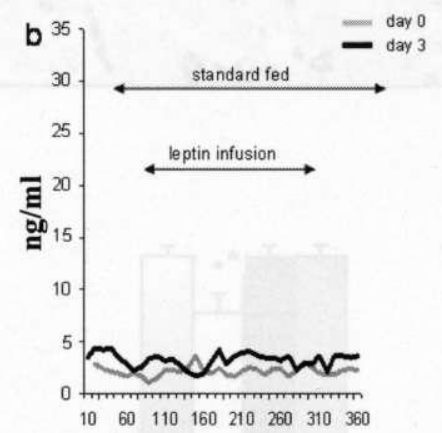

Time, $\min$

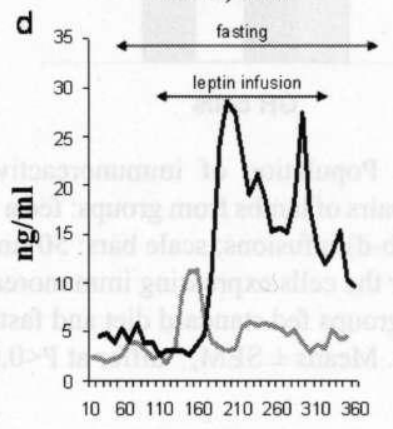

Time, $\min$

Figure 5. The pulsatile pattern of GH release in representative individual sheep on day 0 and day 3 of infusions when fed a standard diet $(\mathrm{a}, \mathrm{b})$ or fasted $72 \mathrm{~h}(\mathrm{c}, \mathrm{d})$ followed by intracerebroventricular infusions of either vehicle $(a, c)$ or leptin $(b, d)$ 


\section{DISCUSSION}

The presented results show that under conditions of acute fasting infusions of leptin into the III ventricle of the brain of prepubertal female lambs suppresses the secretory activity of somatostatin neurons in the hypothalamus, enhances expression of GH mRNA, and increases GH secretion in adenohypophyseal cells and the release of $\mathrm{GH}$ from $\mathrm{GH}$-producing cells into the blood circulation.

The stimulatory effects of dietary restrictions on HPS axis activity of ruminants have been well documented (Thomas et al., 1990; Polkowska et al., 1996). The direct cause of this effect is enhancement of the pulsatile release of GH and its synthesis (Hart et al., 1985; Polkowska et al., 1996). It has also been shown that augmentation of the GH secretory processes is mainly due to impairment of somatostatin secretion. A marked decrease of somatostatin concentration in the hypohysial portal circulation was noted in underfed ovariectomized (OVX) ewes (Thomas et al., 1990). Moreover, reduced somatostatin mRNA levels in the PEV nucleus in the hypothalamus in chronic feed-restricted OVX ewes were observed (Henry et al., 2001).

The results of the presented study show that acute fasting enhances somatostatin in the PEV perikarya and somatostatin stores in the ME nerve terminals. This can be interpreted as simultaneous inhibition of axonal transport and somatostatin release into the portal blood, giving a net result of suppression of somatostatin neurone activity. A similar observation pointing to inhibition of somatostatin output was shown in our previous study on lambs fed a protein-restricted diet (Gładysz et al., 2001). Our results also demonstrate that short starvation affects the secretory activity of the pituitary GH cells in prepubertal female lambs. The increased GH mRNA level in the pituitary somatotrophs can be interpreted as augmentation of GH mRNA synthesis. Enhanced expression of GH mRNA was observed in OVX sheep fed a long-term restricted diet (Thomas et al., 1990). The decreased level of GH observed in the pituitary somatotrophs in fasted sheep could reflect a reduction with time of the hormonal granules due to their elevated release. This phenomenon is consistent with the higher GH plasma concentration observed in these animals. This is in agreement with our earlier study on growing lambs fed a protein-restricted diet, where the enhanced secretory processes in GH-pituitary cells corresponded to a higher GH plasma concentration (Polkowska et al., 1996; Gładysz et al., 2001). So, it can be summarized that short starvation resulted in clearly increased GH mRNA synthesis and also in release of this hormone from pituitary somatotrophic cells, which corresponds with the elevated GH plasma concentration due to increased GH pulse amplitude. The data concerning the augmented release of GH into the blood circulation under conditions of short starvation generally agree with those obtained on OVX lambs or in intact adult 
sheep subjected to an energy-restricted diet. In these animals, the increase in GH plasma concentration was due to the increased amplitude of its pulses (Thomas et al., 1990; Gładysz et al., 2001; Morrison et al., 2001).

Generally, an effect of leptin infusion on HPS axis was observed only in fasted animals. Morphological changes in the somatostatin PVN nucleus perikarya and in the nerve terminals of the ME can be interpreted as suppression of the somatostatin signal. Leptin treatment in fasted sheep intensifies the immunoreactions in the cells forming the somatostatin perikarional centre and shows visibly the increase of somatostatin stores in the nerve terminals in the ME. These changes can be interpreted as inhibition of both the axonal transport from perikarya to nerve terminals and suppression of somatostatin release into the hypophysial portal blood. Moreover, changes in somatostatin secretory dynamics have been observed in rats receiving leptin infusions (Cocchi et al., 1999), which suggests that leptin is involved in somatostatin regulation in this species too.

The direct action of leptin at the hypothalamic level can be mediated through its receptors, which have been identified within regions rich in somatostatin neurons such as the ARC nucleus and the ME (Baratta, 2002; Casanueva and Dieguez, 2005). The expression of a long form of leptin receptor mRNA and leptin binding were increased in the ARC during fasting in rats (Baskin et al., 1998, 1999). Under conditions of malnutrition, an increase in the level of leptin receptor expression in the hypothalamus of ewes also was observed (Dyer et al., 1997).

Moreover, after leptin infusion, visible changes at the level of $\mathrm{GH}$ in the pituitary gland were observed. The enhanced GH mRNA expression and GH in pituitary cells in leptin-infused lambs can suggest a parallel increase in the hormone's synthesis and storage. Simultaneously, in this group of sheep, leptin treatments induced increases in the mean concentrations of $\mathrm{GH}$ in the blood plasma resulting from the increase in pulse amplitude. In summary, the results obtained on leptin-infused, fasted sheep show that increased secretory activity in pituitary somatotrophic cells is correlated with a higher GH plasma concentration, suggesting increased release of this hormone into the blood circulation. Similar results concerning the fluctuation of $\mathrm{GH}$ pulsatile release after leptin treatment were obtained in experiments performed on sheep by other authors (Nagatani et al., 2000; Henry et al., 2001, Morrison et al., 2001). The ability of leptin to increase GH pulse amplitude demonstrated in the presented experiment is in agreement with a previous study on oestradiol-implanted whethers (Nagatani et al., 2000) and also with reports from a study performed on OVX ewe lambs (Morrison et al., 2001). Analogous effects of leptin on GH gene expression in somatotrophic cells were found in pigs (Baratta et al., 2002). Our results are also comparable with those of in vitro studies where leptin-treated adenohypophyseal cell cultures from pig, cattle or rats exhibited a marked increase in basal secretion of $\mathrm{GH}$ 
(Barb et al., 1998; Cocchi et al., 1999; Zieba et al., 2003). The direct relationship between leptin and GH was additionally established by information about the presence of leptin receptors on the level of somatotrophic cells in the pituitary gland in sheep (Iqbal et al., 2000).

\section{CONCLUSIONS}

These results allow the conclusion that short fasting affects the hypothalamopituitary-somatotropic (HPS) axis by enhancement of growth hormone (GH) release via restraining of somatostatin output. Exogenous leptin additionally amplifies this effect by depressing the somatostatin neuronal system and increasing GH synthesis. The results provide evidence that leptin is an important modulator of HPS axis activity in prepubertal female lambs under conditions of nutritional deficiency.

\section{ACKNOWLEDGMENTS}

Highly purified recombinant ovine leptin was provided and kindly donated by Prof. Arieh Gertler from The Hebrew University of Jerusalem, Rehovot, Israel.

The authors would to express their thanks to veterinary surgeon J. Rutkowski for help in the brain surgery.

\section{REFERENCES}

Baratta M., 2002. Leptin - from a signal of adiposity to a hormonal mediator in peripheral tissues. Med. Sci. Monit. 8, RA282-RA292

Baratta M., Saleri R., Mainardi G.L., Valle D., Giustina A., Tamanini C., 2002. Leptin regulates GH gene expression and secretion and nitric oxide production in pig pituitary cells. Endocrinology $143,551-557$

Barb C.R., Yan X., Azain M.J., Kraeling R.R., Rampacek G.B., Ramsay T.G., 1998. Recombinant porcine leptin reduces feed intake and stimulates growth hormone secretion in swine. Domest. Anim. Endocrinol. 15, 77-86

Baskin D.G., Brcininger J.F., Bonigut S., Miller M.A., 1999. Leptin binding in the arcuate nucleus is increased during fasting. Brain Res. 828, 154-158

Baskin D.G., Seeley R.J., Kujiper J.L., Lok S., Weigle D.S., Erickson J.C., Palmiter R.D., Schwartz M.W., 1998. Increased expression of mRNA for the long form of the leptin receptor in the hypothalamus is associated with leptin hypersensivity and fasting. Diabetes $47,538-543$

Brazeau P., Bohlen P., Esch F., Ling N., Wehrenberg W.B., Guillemin R., 1984. Growth hormonereleasing factor from ovine and caprine hypothalamus: isolation, sequence analysis and total synthesis. Biochem. Biophys. Res. Commun. 125, 601-614 
Brazeau P., Vale W., Burgus R.., Ling N., Buthcher M., Rivier J., Guilleman R., 1973. Hypothalamic polypeptide that inhibits the secretion of immunoreactive pituitary growth hormone. Science $179,77-79$

Carro E., Senaris R., Considine R.V., Casanueva F.F., Dieguez C., 1997. Regulation of in vivo growth hormone secretion by leptin. Endocrinology 138, 2203-2206

Casanueva F.F., Dieguez C., 1999. Neuroendocrine regulation and action of leptin. Front. Neuroendocrinol. 20, 317-363

Casanueva F.F., Dieguez C., 2005. Leptin and ghrelin: what is the impact on pituitary function? Rev. Endocr. Metab. Disord. 6, 39-45

Cocchi D., De Gennaro Colonna V., Bagnasco M., Bonacci D., Müller E.E., 1999. Leptin regulates $\mathrm{GH}$ secretion in the rat by acting on GHRH and somatostatinergic functions. J. Endocrinol. 162, 95-99

Dubois M.P., 1971. Misé en évidence par immuno-fluorescence des cellules somatotropes et des cellules á prolactine dans l'hypophyse foetale des bovines. CR Acad. Sci. 272, 433-435

Dyer C.J., Simmons J.M., Matteri R.L., Keisler D.H., 1997. Leptin receptor m RNA is expressed in ewe anterior pituitary and adipose tissues and is differentially expressed in hypothalamic regions of well-fed and feed-restricted ewes. Domest. Anim. Endocrinol. 14, 119-128

Gładysz A., Krejci P., Simunek J., Polkowska J., 2001. Effects of central infusions of neuropeptide $\mathrm{Y}$ on the somatotrophic axis in sheep fed on two levels of protein. Acta Neurobiol. Exp. 61, 255-266

Hart I.C., Chadwick P.M.E., Coert A., James S., Simmons A.D., 1985. Effect of different growth hormone-releasing factors on the concentrations of growth hormone, insulin and metabolites in the plasma of sheep maintained in positive and negative energy balance. J. Endocrinol. 105, 113-119

Henry B.A., Goding J.W., Alexander W.S., Tilbrook A.J., Canny B.J., Dunshea F., Rao A., Mansell A., Clarke I.J., 1999. Central administration of leptin to ovariectomized ewes inhibits food intake without affecting the secretion of hormones from pituitary gland: evidence for a dissociation of effects on appetite and neuroendocrine function. Endocrinology 140, 1175-1182

Henry B.A., Goding J.W., Tilbrook A.J., Dunshea F., Clarke I.J., 2001. Intracerebroventricular infusion of leptin elevates the secretion of luteinizing hormone without affecting food intake in long-term food-restricted sheep, but increases growth hormone irrespective of bodyweight. J. Endocrinol. 168, 67-77

Iqbal J., Pompolo S., Considine R.V., Clarke I.J., 2000. Localization of leptin receptor-like immunoreactivity in the corticotropes, somatotropes and gonadotropes in the ovine anterior pituitary. Endocrinology 141, 1515-1520

Merriam G.R., Wachter K.W., 1982. Algorithms for the study of episodic hormone secretion. Amer. J. Physiol. 243, E310-E318

Morrison C.D., Daniel J.A., Holmberg B.J., Dijane J., Raver N., Gertler A., Keisler D.H., 2001. Central infusion of leptin into well-fed and undernourished ewe lambs; effects on feed intake and serum concentrations of growth hormone and luteinizing hormone. J. Endocrinol. 168, 317 324

Nagatani S., Zeng Y., Keisler D.H., Foster D.L., Jaffe C.A., 2000. Leptin regulates pulsatile luteinizing hormone and growth hormone secretion in the sheep. Endocrinology 141, 3965-3397

Polkowska J., Krejči P., Snochowski M., 1996. The long-term effect of low protein diet on the somatostatin hypothalamic neuronal system and the pituitary growth hormone cells in growing ewe. Exp. Clin. Endocrinol. 104, 59-66 
Slaba J., Krejči P., Skarda J., Huybrechts L.M., Decuypere E., Hermann E., 1994. Plasma profiles of somatotropin and IGF-I in dairy cows following application of two preparations of recombinant bovine somatotropin in a sustained release vehicle. Physiol. Res. 43, 37-43

Stupnicki R., Kula E., 1982. Direct radioimmunoassay of progesterone in human plasma. Endokrinologie 80, 1-7

Tartaglia L., Dembski M., Weng X., et al., 1995. Identification and expression cloning of a leptin receptor, OB-R. Cell 83, 1263-1271

Thomas G.B., Mercer J.E., Karalis T., Rao A., Cummings J.T., Clarke I.J., 1990. Effect of restricted feeding on the concentrations of growth hormone $(\mathrm{GH})$, gonadotropins, and prolactin (PRL) in plasma, and on the amounts of messenger ribonucleic acid for $\mathrm{GH}$, gonadotropin subunits and PRL in the pituitary glands of adult ovariectomized ewes. Endocrinology 126, 1361-1367

Traczyk W., Przekop F., 1963. Methods of investigation of the function of the hypothalamus and hypophysis in chronic experiments in sheep. Acta. Physiol. Pol. 14, 217-226

Welento J., Szteyn S., Milart Z., 1969. Observations on the stereotaxic configuration of the hypothalamic nuclei in the sheep. Anat. Anz. 124, 1-27

Zhang Y., Proenca R., Maffei M., Barone M., Leopold L., Friedman J.M., 1994. Positional cloning of the mouse obese gene and its human homologue. Nature 372, 425-432

Zieba D.A., Amstalden M., Morton S., Gallino J.L., Edwards J. F., Harms P. G., Williams G.L., 2003. Effects of leptin on basal and GHRH-stimulated GH secretion from the bovine adenohypophysis are dependent upon nutritional status. J. Endocrinol. 178, 83-89 